\title{
Aplikasi Software Watercad V8i Untuk Evaluasi dan Pengembangan Sistem Jaringan Distribusi Air Bersih di Desa Rejosari Kecamatan Bantur Kabupaten Malang
}

\author{
Aaron Petrova Abriani ${ }^{1 *}$, Janu Ismoyo $^{1}$, Riyanto Haribowo ${ }^{1}$ \\ ${ }^{1}$ Jurusan Teknik Pengairan, Fakultas Teknik, Universitas Brawijaya, \\ J1. M.T. Haryono 167, Malang, 65145, INDONESIA
}

*Korespondensi Email: aaronpetrova@ gmail.com

\begin{abstract}
Rejosari Village is part of the Malang Regency area, the need for clean water in this area has not been fulfilled properly. It is necessary to study and evaluate the provision of clean water for the Rejosari Village community in terms of quantity, quality and continuity. Efforts that can be made to meet the need for clean water in this area are by developing the existing clean air network and by maximizing the potential of the Tunjungsari spring in Bantur Village. The results of the evaluation of the need for clean water in existing conditions (2019) with a discharge of 5 liters / second are able to serve $100 \%$ of the number of customers in the service area of HIPPAM Sumber Hidup, which can serve 320 customers. For the development stage of the clean water distribution network in Rejosari Village, it is planned to increase the service area to Tunjungsari Hamlet and also increase the percentage of services for the hamlets that have been served. Network development and replacement of the diameter of the transmission pipe with a diameter larger than the original 3 inches to 4 inches in diameter need to be done to meet all the planning criteria in accordance with the latest SNI. After analyzing and calculating with the WatercadV8i program, it was found that the distribution network system in the study area was feasible and could function properly and could fulfill all customer needs.
\end{abstract}

Keywords: Network Development, Provision of Clean Water, WaterCAD

Abstrak: Desa Rejosari merupakan bagian dari wilayah Kabupaten Malang, kebutuhan akan air bersih di daerah ini masih belum dapat terpenuhi secara baik. Diperlukan sebuah kajian dan evaluasi tentang penyediaan air bersih untuk masyarakat Desa Rejosari baik secara kuantitas, kualitas dan kontinuitas. Upaya yang bisa dilakukan untuk memenuhi kebutuhan air bersih di wilayah ini yaitu dengan cara mengembangkan jaringan air bersih yang sudah ada serta dengan cara memaksimalkan potensi sumber mata air Tunjungsari yang berada di Desa Bantur. Hasil evaluasi kebutuhan air bersih pada kondisi existing (tahun 
2019) dengan debit sebesar 5 liter/detik mampu melayani 100\% dari jumlah pelanggan di daerah pelayanan HIPPAM Sumber Hidup yaitu dapat melayani 320 pelanggan. Untuk tahap pengembangan jaringan distribusi air bersih di Desa Rejosari direncanakan untuk menambah daerah pelayanan menuju Dusun Tunjungsari dan juga penambahan prosentase pelayanan untuk Dusun yang sudah terlayani. Pengembangan jaringan dan penggantian diameter pipa transmisi dengan diameter yang lebih besar dari awalnya 3 inchi di ganti dengan diameter 4 inchi perlu dilakukan untuk bisa memenuhi seluruh kriteria perencanaan yang sesuai dengan pedoman SNI. Setelah dilakukan analisa dan perhitungan dengan program Watercad V8i didapatkan bahwa sistem jaringan distribusi pada daerah studi layak dan dapat berfungsi dengan baik serta mampu memenuhi seluruh kebutuhan pelanggan.

Kata kunci: Pengembangan Jaringan, Penyediaan Air Bersih, WaterCAD

\section{Pendahuluan}

Desa Rejosari merupakan bagian dari wilayah Kabupaten Malang, kebutuhan akan air bersih di daerah ini masih belum dapat terpenuhi secara baik. Untuk kondisi sekarang, keperluan air minum dan air bersih beserta (MCK) di Daerah Rejosari Kecamatan Bantur Kabupaten Malang menggunakan jaringan pipa yang telah dibangun pada tahun 2002 yang berasal dari swadaya masyarakat dan dikelola oleh HIPPAM Sumber Hidup, dengan memanfaatkan sumber mata air Tunjungsari yang berada di Desa Bantur. Pemanfaatan sumber mata air Tunjungsari belum dioptimalkan secara baik, sehingga menyebabkan Desa Rejosari sampai saat ini masih kekurangan pasokan air bersih. Seiring dengan meningkatnya jumlah penduduk, kebutuhan air juga akan terus semakin bertambah. Sistem jaringan distribusi air bersih yang tersedia sekarang sudah tidak mampu lagi untuk memenuhi seluruh kebutuhan masyarakat di Desa Rejosari, maka dibutuhkan suatu upaya untuk pengembangan sistem jaringan perpipaan yang lebih baik lagi.

Upaya yang dapat di lakukan untuk mengatasi permasalahan air bersih di Desa Rejosari adalah dengan mengoptimalkan debit pada sumber mata air Tunjungsari yang sampai sekarang belum dimanfaatkan secara baik dan maksimal, yang terletak di Desa Bantur Kabupaten Malang. Sumber mata air Tunjungsari mempunyai kapasitas debit sebesar 80 liter/detik. Debit air yang telah dipakai untuk masyarakat Desa Rejosari untuk saat ini sebesar 5 liter/detik. Sistem jaringan air bersih yang belum optimal diakibatkan oleh perencanaan jaringan yang tidak memperhitungkan pola kenaikan dari kebutuhan pelanggan. Analisis hidraulik yang akan di lakukan meliputi pengaruh dari tinggi tekan hidraulik serta kapasitas diameter pada pipa untuk mengalirkan debit sesuai rencana.

Dalam studi ini diharapkan mampu untuk menyajikan evaluasi terhadap upaya yang harus dilakukan untuk memenuhi dan meningkatkan pelayanan kepada masyarakat di Desa Rejosari terkait dengan penyediaan air bersih secara baik dan benar ditinjau dari segi kualitas, kuantitas dan kontinuitas. Sehingga kebutuhan air masyarakat Desa Rejosari bisa terpenuhi secara optimal dan merata. 


\section{Data dan Metode Penelitian}

Ditinjau dari letak geografisnya Kecamatan Bantur Kabupaten Malang terletak pada

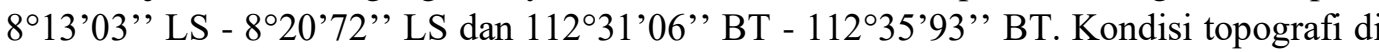
daerah Kecamatan Bantur Kabupaten Malang sebagian besar berupa dataran tinggi (perbukitan). Secara administratif Kecamatan Bantur terbagi menjadi 10 desa, 34 dusun, 96 rukun warga dan 492 rukun tetangga. Dalam melakukan kajian terhadap sistem jaringan distribusi air bersih dibutuhkan tahap-tahap penelitian yaitu mengumpulkan data pendukung dan data teknis, kemudian melakukan simulasi dan analisa dengan menggunakan aplikasi WaterCAD V8i.

\subsection{Data}

Dalam melakukan kajian terhadap sistem jaringan distribusi bersih dibutuhkan tahaptahap penelitian yaitu mengumpulkan data pendukung dan data teknis, data yang diperlukan didalam studi ini yaitu:

1. Data Penduduk

Data ini sangat diperlukan dalam proses perhitungan jumlah penduduk yang akan terlayani kebutuhan air bersihnya dan tingkat pelayanan yang harus dipenuhi. Data penduduk yang digunakan dalam studi ini diperoleh dari data arsip kependudukan di Kantor Kecamatan Bantur. Data penduduk untuk masing-masing dusun di Desa Rejosari di sajikan pada Tabel 1 sebagai berikut.

Tabel 1: Data Penduduk Masing-masing Dusun

\begin{tabular}{ccc}
\hline No & Dusun & Jumlah Penduduk (Jiwa) \\
\hline \hline 1 & Krajan & 1820 \\
2 & Jeding & 1588 \\
3 & Tunjungsari & 896 \\
\hline
\end{tabular}

2. Data Debit Sumber Mata Air

Data ini diperlukan untuk mengetahui kemampuan sumber air dalam menyediakan total kapasitas kebutuhan air bersih yang direncanakan. Data debit sumber mata air Tunjungsari diperoleh dari data hasil pengukuran yang dilakukan oleh PDAM unit Bantur pada tahun 2016 yaitu sebesar 80 liter/detik. Debit air yang telah dipakai untuk masyarakat Desa Rejosari untuk saat ini sebesar 5 liter/detik.

3. Data Skema dan Data Teknis Jaringan Pipa

Data skema dan data teknis jaringan instalasi perpipaan digunakan sebagai acuan dalam perencanaan pengembangan jaringan yang akan dilakukan dan untuk mengetahui keadaannya sekarang serta untuk dievaluasi terkait rencana yang akan dilakukan pengembangan. Data skema jaringan pipa diperoleh dari hasil survey langsung ke lapangan dengan menggunakan GPS, dibantu oleh seorang teknisi dari HIPPAM Sumber Hidup yang sudah memahami letak dan kondisi jaringan pipa yang sudah ada. Pipa yang dipakai untuk mengalirkan air ke masyarakat dibagi menjadi dua jenis yaitu pipa untuk transmisi dan pipa untuk distribusi. Pipa transmisi merupakan pipa yang digunakan sebagai aliran air dari sumber menuju tandon. Sedangkan pipa distribusi yaitu pipa yang digunakan untuk mengalirkan air bersih dari tandon ke wilayah pelanggan. Pipa yang dipakai di jaringan transmisi adalah 
pipa besi berdiameter 3 inchi, sedangkan pipa distribusi menggunakan jenis pipa PVC berdiameter 3 inchi, 2,5 inchi dan 2 inchi. Pada saat ini jumlah pelanggan dari Hippam Sumber Hidup adalah 320 Sambungan Rumah (SR).

\subsection{Metode Penelitian}

Agar tercapainya tujuan yang diharapkan, dibutuhkan satu cara penyelesaian secara sistematis agar mencapai hasil yang optimal. Berikut adalah langkah-langkah yang dilakukan dalam penyelesaian studi:

1. Mengumpulkan data-data yang diperlukan yaitu data teknis jaringan perpipaan. Data jumlah penduduk, data jumlah pelanggan existing, debit sumber mata air, elevasi, peta daerah layanan dan data teknis jaringan pipa.

2. Menghitung jumlah proyeksi penduduk sampai dengan tahun 2039 menggunakan persamaan Eksponensial, Aritmatik, dan Geometrik [1].

3. Melakukan uji kesesuaian data dari metode proyeksi penduduk kemudian dibandingkan koefisien korelasi serta nilai standar deviasi.

4. Melakukan analisa terhadap kebutuhan air serta kemampuan sumber untuk area pelayanan.

5. Melakukan simulasi dengan aplikasi WaterCAD V8i

Analisa sistem jaringan perpipaan di Desa Rejosari Kecamatan Bantur Kabupaten Malang ini dilakukan berdasarkan data-data yang telah diperoleh. Pada saat simulasi sistem jaringan perpipaan pada program WaterCAD V8i [2] dibutuhkan langkah pengerjaan seperti berikut:

1. Membuka dan memberi nama lembar kerja baru pada instalasi jaringan perpipaan dengan format WaterCAD.

2. Melakukan pengisian pada tahap pembuatan file yang baru sistem jaringan perpipaan

3. Menggambarkan instalasi jaringan perpipaan

4. Melaksanakan running pada instalasi jaringan perpipaan dan juga melakukan analisisa terhadap kondisi aliran yang diperoleh (report). Jika dari hasil yang diperoleh tidak sesuai dengan kriteria perencanaan maka pemodelan akan diperbaiki lagi untuk setiap komponen instalasi jaringan perpipaan yang ada sampai mendapatkan hasil seperti yang telah direncanakan.

\section{Hasil dan Pembahasan}

Pada studi evaluasi dan pengembangan sistem jaringan distribusi air bersih di Desa Rejosari dilakukan perhitungan yang pertama yaitu mengevaluasi kondisi existing tahun 2019 jaringan distribusi air bersih, kemudian melakukan perhitungan jumlah proyeksi penduduk [1] dari tahun 2020 sampai tahun 2039. Setelah didapatkan jumlah penduduk sesuai dengan metode proyeksi yang dipilih, maka selanjutnya menganalisis kemampuan pelayanan dan perhitungan kebutuhan air bersih. Perhitungan jumlah kebutuhan air bersih meliputi kebutuhan air rata-rata, kebutuhan air maksimum, dan kebutuhan air bersih pada jam puncak [3]. Analisa pada aplikasi WaterCAD V8i dapat dilakukan setelah data-data telah selesai diinput pada sistem dan pemodelan jaringan perpipaan telah berhasil direncanakan. Ketika sudah selesai disimulasikan bisa dilakukan evaluasi untuk kondisi 
hidrolisnya. Apabila dari hasil yang diperoleh tidak sesuai dengan kriteria perencanaan maka pemodelan akan diperbaiki lagi untuk setiap komponen instalasi jaringan perpipaan yang ada sampai mendapatkan hasil seperti yang telah direncanakan [2].

\subsection{Proyeksi Pertumbuhan Penduduk}

Metode yang akan digunakan untuk perhitungan jumlah proyeksi pertumbuhan penduduk ada tiga macam yaitu, metode eksponensial, metode geometrik, dan metode aritmatik [1]. Setelah selesai menghitung proyeksi penduduk dengan ketiga metode tersebut, didapatkanlah hasil dari tiap-tiap metode proyeksi, selanjutnya menghitung nilai koefisien korelasi serta standar deviasinya. Penentuan metode proyeksi penduduk yang dipilih untuk perhitungan selanjutnya berdasarkan nilai standar deviasi yang paling kecil dan koefisien korelasi yang terbesar mendekati +1 . Proyeksi jumlah pertumbuhan penduduk dikelompokkan kedalam tiga wilayah per masing-masing dusun. Didalam studi ini yaitu Dusun Krajan, Dusun Jedding, Dusun Tunjungsari.

Tabel 2: Prosentase Laju Pertumbuhan Penduduk Desa Rejosari

\begin{tabular}{ccccc}
\hline \multirow{2}{*}{ No } & Tahun & Jumlah Penduduk (Jiwa) & \multicolumn{2}{c}{ Pertumbuhan Penduduk } \\
& Jiwa & $\%$ \\
\hline \hline 1 & 2010 & 6761 & & \\
2 & 2011 & 6770 & 9 & $0,13 \%$ \\
3 & 2012 & 6778 & 8 & $0,12 \%$ \\
4 & 2013 & 6781 & 3 & $0,04 \%$ \\
5 & 2014 & 6796 & 15 & $0,22 \%$ \\
6 & 2015 & 6811 & 15 & $0,22 \%$ \\
7 & 2016 & 6840 & 29 & $0,43 \%$ \\
8 & 2017 & 6834 & -6 & $-0,09 \%$ \\
9 & 2018 & 6842 & 8 & $0,12 \%$ \\
10 & 2019 & 6864 & 22 & $0,32 \%$ \\
\hline \hline
\end{tabular}

Tabel 2 merupakan perhitungan yang telah dilakukan berdasarkan data jumlah penduduk Desa Rejosari dari tahun 2010-2019 didapatkan rata-rata pertumbuhan penduduk sebesar $0,17 \%$ per tahun. Rata-rata pertumbuhan penduduk yang telah didapat tersebut digunakan untuk perhitungan proyeksi pertumbuhan penduduk masing-masing dusun sampai dengan tahun 2039 .

Tabel 3: Rekapitulasi Perhitungan Standar Deviasi

\begin{tabular}{cccc}
\hline \multirow{2}{*}{ Dusun } & Aritmatik & Metode Proyeksi \\
& Geometrik & Eksponensial \\
\hline Krajan & 18,9987 & 19,3054 & 19,3219 \\
Jedding & 16,5769 & 16,8445 & 16,8589 \\
Tunjungsari & 9,3532 & 9,5042 & 9,5123 \\
\hline
\end{tabular}


Tabel 4: Rekapitulasi Perhitungan Koefisien Korelasi

\begin{tabular}{lccc}
\hline \multicolumn{1}{c}{ Dusun } & Aritmatik & Metode Proyeksi \\
& Geometrik & Eksponensial \\
\hline Krajan & 1,0000000 & 0,9999897 & 0,9999897 \\
Jedding & 1,0000000 & 0,9999897 & 0,9999897 \\
Tunjungsari & 1,0000000 & 0,9999897 & 0,9999897 \\
\hline
\end{tabular}

Berdasarkan perhitungan koefisien korelasi pada Tabel 3 dan standar deviasi pada Tabel 4, maka metode proyeksi aritmatik dipilih untuk digunakan dalam perhitungan proyeksi penduduk untuk setiap Dusun, karena memiliki nilai standar deviasi yang paling kecil dan koefisien korelasi yang terbesar. Berikut ini merupakan perhitungan proyeksi penduduk dengan metode aritmatik disajikan pada Tabel 5.

Tabel 5: Proyeksi Pertumbuhan Penduduk dengan Metode Aritmatik

\begin{tabular}{ccccc}
\hline No & Tahun & Krajan & $\begin{array}{c}\text { Dusun } \\
\text { Jedding }\end{array}$ & \begin{tabular}{c} 
Tunjungsari \\
\hline
\end{tabular} \\
\hline & 2019 & 1820 & 1588 & 896 \\
2 & 2020 & 1823 & 1591 & 898 \\
3 & 2022 & 1826 & 1593 & 899 \\
4 & 2023 & 1829 & 1596 & 901 \\
5 & 2024 & 1832 & 1599 & 902 \\
6 & 2025 & 1838 & 1601 & 904 \\
7 & 2026 & 1841 & 1604 & 905 \\
8 & 2027 & 1844 & 1607 & 907 \\
9 & 2028 & 1848 & 1612 & 908 \\
10 & 2029 & 1851 & 1615 & 910 \\
11 & 2030 & 1854 & 1617 & 911 \\
12 & 2031 & 1857 & 1620 & 913 \\
13 & 2032 & 1860 & 1623 & 914 \\
14 & 2033 & 1863 & 1625 & 916 \\
15 & 2034 & 1866 & 1628 & 917 \\
16 & 2035 & 1869 & 1631 & 919 \\
17 & 2036 & 1872 & 1633 & 922 \\
18 & 2037 & 1875 & 1636 & 923 \\
19 & 2038 & 1878 & 1639 & 925 \\
20 & 2039 & 1881 & 1641 & 926 \\
\hline
\end{tabular}

Tabel 6: Jumlah Penduduk Sampai Dengan Tahun 2039

\begin{tabular}{ccc}
\hline No & Dusun & Jumlah Penduduk (Jiwa) \\
\hline \hline 1 & Krajan & 1881 \\
2 & Jeding & 1641 \\
3 & Tunjungsari & 926 \\
\hline
\end{tabular}


Tebel 6 diatas merupakan proyeksi jumlah penduduk untuk daerah pelayanan yaitu Dusun Krajan, Dusun Jedding, dan Dusun Tunjungsari hingga tahun 2039 menggunakan metode Aritmatik yaitu sebesar 4449 jiwa.

\subsection{Proyeksi Kebutuhan Air Bersih}

Kebutuhan air baku pada dasarnya terdiri dari dua macam kebutuhan, yaitu kebutuhan air domestik serta kebutuhan air non domestik [4]. Pada studi perencanaan ini berdasar dari Peraturan Menteri PU Penyelenggaraan Pengembangan SPAM Tahun 2007 Desa Rejosari, Kabupaten Malang termasuk pada kategori desa karena Desa Rejosari dihuni kurang dari 20.000 jiwa, sehingga kebutuhan air setiap orang di Desa Rejosari sebesar 60 liter/orang/hari [3]. Sedangkan kebutuhan non domestik ditujukan untuk berbagai fasilitas umum berdasarkan Peraturan Menteri Pekerjaan Umum Tentang Penyelenggaraan Pengembangan SPAM tingkat pelayanan air untuk kebutuhan non domestik sebesar 15\% [3] dari kebutuhan domestik.

Pemakaian air pada lokasi studi mengalami perbedaan pada tiap jamnya karena terjadi fluktuasi pada setiap jam yang disebabkan adanya pengaruh pemakaian/faktor beban konsumen [3].

$>$ Kebutuhan air rata-rata $=$ Kebutuhan domestik + Kebutuhan non domestik

$>$ Kebutuhan air maksimum $=1,15 \times$ Kebutuhan air rata-rata

$>$ Kebutuhan jam puncak $=1,56 \times$ Kebutuhan air rata-rata

Perhitungan kebutuhan air bersih di Dusun Krajan, Dusun Jedding, dan Dusun Tunjungsari pada tahun 2039 dengan prosentase keterlayanan 100\% dan kehilangan air sebesar 20\% disajikan pada Tabel 7 berikut:

Tabel 7: Rekapitulasi Kebutuhan Air Bersih

\begin{tabular}{ccccc}
\hline No & Dusun & Tahun & $\begin{array}{c}\text { Jumlah Penduduk } \\
(\text { Jiwa })\end{array}$ & $\begin{array}{c}\text { Kebutuhan Air } \\
(\mathrm{l} / \mathrm{dt})\end{array}$ \\
\hline \hline 1 & Krajan & 2039 & 1881 & 2,07 \\
2 & Jedding & 2039 & 1641 & 1,81 \\
3 & Tunjungsari & 2039 & 926 & 1,02 \\
\hline \hline & Jumlah & 4449 & 4,90 \\
\hline
\end{tabular}

Tabel 8: Kebutuhan Air Bersih Tiap Junction

\begin{tabular}{ccccccc}
\hline No & $\begin{array}{c}\text { Nama } \\
\text { Junction }\end{array}$ & Elevasi & $\begin{array}{c}\text { Jumlah Penduduk } \\
\text { Terlayani } \\
(\text { Jiwa })\end{array}$ & $\begin{array}{c}\text { Kebutuhan } \\
\text { Air } \\
((\text { lt/org/hr) }\end{array}$ & $\begin{array}{c}\text { Total } \\
\text { Kebutuhan } \\
\text { Air } \\
(1 / \mathrm{dt})\end{array}$ & $\begin{array}{c}\text { Harian } \\
\text { Maksimum }\end{array}$ \\
\hline 1 & J-41 & 372 & 269 & 60 & 0,2578 & 0,30 \\
2 & J-42 & 379 & 672 & 60 & 0,6440 & 0,74 \\
3 & J-43 & 379 & 416 & 60 & 0,3987 & 0,46 \\
4 & J-44 & 370 & 524 & 60 & 0,5022 & 0,58 \\
5 & J-45 & 353 & 377 & 60 & 0,3613 & 0,42 \\
6 & J-46 & 342 & 424 & 60 & 0,4063 & 0,47 \\
7 & J-47 & 352 & 392 & 60 & 0,3757 & 0,43 \\
\hline
\end{tabular}


Lanjutan Tabel 8: Kebutuhan Air Bersih Tiap Junction

\begin{tabular}{ccccccc}
\hline No & $\begin{array}{c}\text { Nama } \\
\text { Junction }\end{array}$ & Elevasi & $\begin{array}{c}\text { Jumlah Penduduk } \\
\text { Terlayani } \\
(\text { Jiwa })\end{array}$ & $\begin{array}{c}\text { Kebutuhan } \\
\text { Air } \\
((\mathrm{lt} / \text { /org/hr) }\end{array}$ & $\begin{array}{c}\text { Total } \\
\text { Kebutuhan } \\
\text { Air } \\
(\mathrm{l} / \mathrm{dt})\end{array}$ & $\begin{array}{c}\text { Harian } \\
\text { Maksimum }\end{array}$ \\
\hline \hline 8 & J-48 & 367 & 448 & 60 & 0,4293 & 0,49 \\
9 & J-64 & 373 & 126 & 60 & 0,1208 & 0,14 \\
10 & J-65 & 363 & 136 & 60 & 0,1303 & 0,15 \\
11 & J-66 & 361 & 164 & 60 & 0,1572 & 0,18 \\
12 & J-67 & 358 & 156 & 60 & 0,1495 & 0,17 \\
13 & J-68 & 353 & 168 & 60 & 0,1610 & 0,19 \\
14 & J-69 & 356 & 176 & 60 & 0,1687 & 0,19 \\
\hline \hline
\end{tabular}

Dari Tabel 8 diatas maka didapatkan total kebutuhan air untuk memenuhi Dusun Krajan, Dusun Jedding dan Dusun Tunjungsari adalah sebesar 4,90 1/dt.

\subsection{Perhitungan Kebutuhan Air Bersih Kondisi Existing}

Jumlah pelanggan dari Hippam Sumber Hidup pada kondisi existing (Tahun 2019) mencakup 320 SR. Dengan asumsi jumlah jiwa/rumah adalah 4 orang, maka total jumlah penduduk yang terlayani adalah sebesar 1280 jiwa. Setelah didapat jumlah penduduk untuk daerah yang terlayani selanjutnya dihitung kebutuhan air bersih untuk tiap-tiap junction, yang disajikan pada Tabel 9 berikut:

Tabel 9: Kebutuhan Air Bersih Tiap Junction Pada Kondisi Existing

\begin{tabular}{ccccccc}
\hline No & $\begin{array}{c}\text { Nama } \\
\text { Junction }\end{array}$ & Elevasi & $\begin{array}{c}\text { Jumlah Penduduk } \\
\text { Terlayani } \\
(\text { Jiwa })\end{array}$ & $\begin{array}{c}\text { Kebutuhan } \\
\text { Air } \\
((\text { lt/org/hr })\end{array}$ & $\begin{array}{c}\text { Total } \\
\text { Kebutuhan } \\
\text { Air } \\
(\mathrm{l} / \mathrm{dt})\end{array}$ & $\begin{array}{c}\text { Harian } \\
\text { Maksimum }\end{array}$ \\
\hline 1 & J-41 & 372 & 96 & 60 & 0,0920 & 0,11 \\
2 & J-42 & 379 & 224 & 60 & 0,2147 & 0,25 \\
3 & J-43 & 379 & 196 & 60 & 0,1878 & 0,22 \\
4 & J-44 & 370 & 148 & 60 & 0,1418 & 0,16 \\
5 & J-45 & 353 & 128 & 60 & 0,1227 & 0,14 \\
6 & J-46 & 342 & 188 & 60 & 0,1802 & 0,21 \\
7 & J-47 & 352 & 136 & 60 & 0,1303 & 0,15 \\
8 & J-48 & 367 & 164 & 60 & 0,1572 & 0,18 \\
\hline \hline \multicolumn{7}{c}{ Jumlah } \\
\hline
\end{tabular}

Setelah dilakukan perhitungan, maka didapatkan total kebutuhan air bersih yang ada di Dusun Krajan dan Dusun Jedding pada kondisi existing tahun 2019 adalah 1,41 liter/dt.

\subsection{Evaluasi Hasil Simulasi Program WaterCAD V8i untuk Kondisi Existing}

Besarnya kehilangan tinggi tekan mayor pada studi ini dihitung menggunakan metode Hazen-Williams [5]. Metode ini sering digunakan oleh para teknisi dalam analisa sistem pipa bertekanan. Analisa dilakukan dengan waktu simulasi 24 jam dan kondisi tidak 
permanen. Corak variasi kebutuhan air bersih harian yang terjadi pada titik simpul dihitung dengan metode pendekatan penelitian corak fluktuasi kebutuhan air bersih harian yang dilakukan oleh DPU Ditjen Cipta Karya Direktorat Air Bersih [6]. Tanda hijau yang muncul pada Calculation Summary dari hasil running program WaterCAD V8i menunjukkan tidak ada masalah dengan simulasi yang dijalankan.

Jaringan air bersih yang ada di Desa Rejosari pada saat ini melayani 320 sambungan rumah. Dengan kondisi $100 \%$ penduduk terlayani, jumlah penduduk yang terlayani yaitu 1280 jiwa. Jenis pipa yang digunakan di jaringan transmisi adalah pipa Galvanized Iron dengan diameter 3 inchi dan panjang $1550 \mathrm{~m}$, sedangkan pipa distribusi menggunakan pipa jenis PVC dengan diameter 3 inchi, 2,5 inchi dan 2 inchi serta memiliki panjang $3280 \mathrm{~m}$. Setelah semua data di input pada program WaterCAD V8i, selanjutnya dilakukan simulasi sistem jaringan pipa serta menganalisisnya. Hasil simulasi pada pompa dan tandon disajikan pada Gambar 1 berikut.

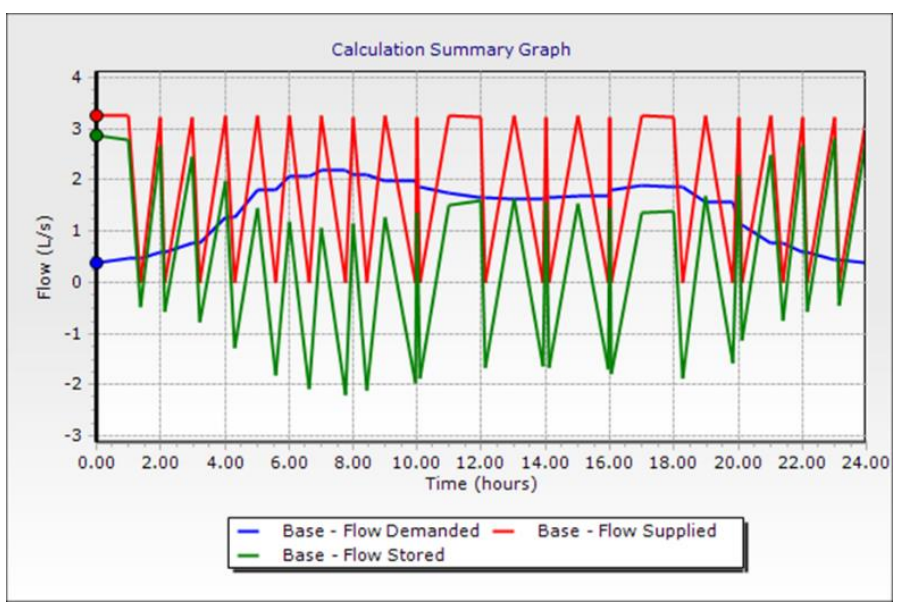

Gambar 1: Grafik Hasil Simulasi pada Pompa dan Tandon

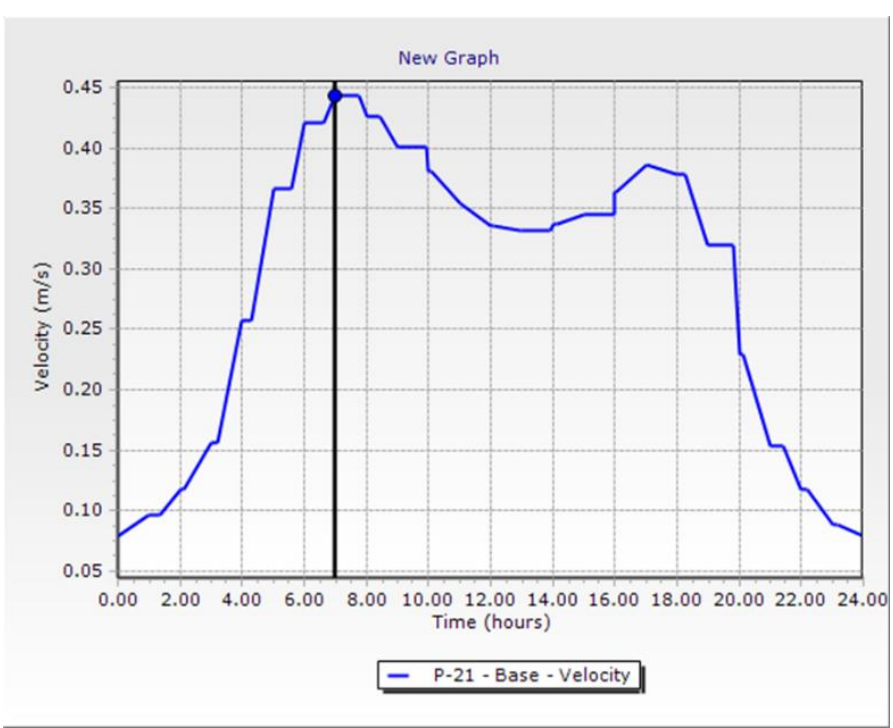

Gambar 2: Grafik Fluktuasi Kecepatan pada Pipa P.21 


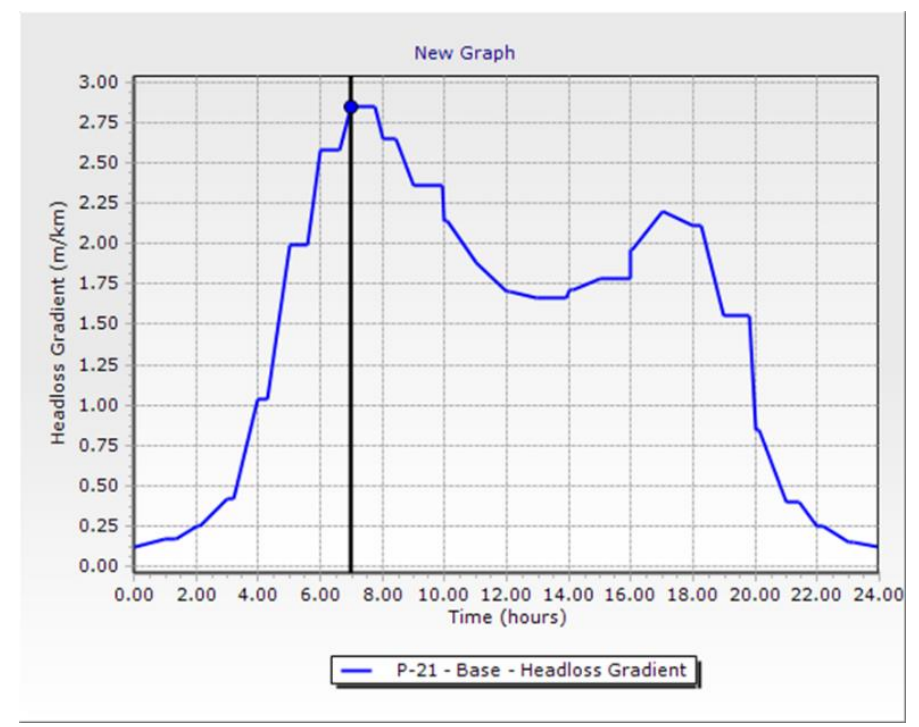

Gambar 3: Grafik Fluktuasi Headloss Gradient pada Pipa P.21

Gambar 2 dan Gambar 3 merupakan hasil simulasi yang dilakukan dengan program WaterCAD V8i pada Pipa 21, kondisi jaringan pipa saat kebutuhan maksimum yaitu pada pukul 07.00 dapat diketahui:

* Kecepatan berkisar antara 0,08-0,44 m/detik. Kecepatan tertinggi terjadi pada saat pukul 07.00 sebesar $0,44 \mathrm{~m} /$ detik dan kecepatan terendah terjadi pada pukul 00.00 sebesar $0,08 \mathrm{~m} /$ detik. Pada pukul 00.00 kecepatannya lebih rendah dari kecepatan minimum yang diijinkan yaitu $0,1 \mathrm{~m} /$ detik. Kondisi ini diakibatkan oleh kebutuhan debit yang sangat kecil pada saat jam 00.00-01.00. Walaupun kecepatannya ada dibawah batas minimum yang diperbolehkan, akan tetapi kondisi seperti ini bisa diterima dikarenakan terjadi pada jam minimum penggunaan air.

* Berdasarkan hasil simulasi yang telah dijalankan pada sistem jaringan pipa P.21 dapat diperoleh nilai headloss gradient $2,85 \mathrm{~m} / \mathrm{km}$ pada pukul 07.00 .

* Berdasarkan hasil simulasi yang telah dijalankan pada jaringan pipa distribusi dari tandon sampai ke daerah layanan yaitu dari P.19 - P.48 didapatkan angka dari headloss gradient yang telah sesuai dengan SNI yang diijinkan yaitu antara 0-15 $\mathrm{m} / \mathrm{km}$.

Hasil evaluasi kebutuhan air bersih pada kondisi existing (tahun 2019) dengan debit sebesar 5 liter/detik mampu melayani 100\% dari jumlah SR di daerah pelayanan HIPPAM Sumber Hidup yaitu dapat melayani 320 SR.

\subsection{Evaluasi Hasil Simulasi Program WaterCAD V8i untuk Tahap Pengembangan}

Kondisi jaringan yang ada sekarang hanya mampu untuk melayani kebutuhan pelanggan yang sudah ada, untuk tahap pengembangan yang lebih besar dan cakupan yang bertambah diperlukan analisa lebih lanjut untuk setiap komponen dari sistem jaringan pipa yang ada. Setelah dilakukan evaluasi berdasarkan jaringan pipa yang sudah ada, maka terdapat beberapa komponen yang perlu dilakukan penggantian agar upaya pendistribusian air bersih berjalan sesuai rencana serta bisa memenuhi seluruh kriteria perencanaan yang 
sesuai dengan pedoman SNI. Diperlukan penggantian diameter pipa transmisi dengan diameter yang lebih besar dari awalnya 3 inchi di ganti dengan diameter 4 inchi dan pada jaringan distribusi perlu dilakukan penggantian pada pipa P.19-P.22 dari diameter awalnya 3 inchi di ganti dengan diameter 3.5 inchi.

Perencanaan pengembangan jaringan air bersih di Desa Rejosari di proyeksikan sampai dengan tahun 2039. Untuk keadaan $100 \%$ pelanggan terlayani, total penduduk di Desa Rejosari sampai dengan tahun 2039 yaitu 4449 jiwa. Total kebutuhan air untuk memenuhi 3 Dusun di Desa Rejosari yaitu Dusun Krajan, Dusun Jedding dan Dusun Tunjungsari adalah sebesar 4,90 1/dt. Pada tahap pengembangan ini pipa yang digunakan di jaringan transmisi adalah pipa jenis Galvanized Iron dengan diameter 4 inchi dengan panjang 1550 $\mathrm{m}$, sedangkan pipa distribusi menggunakan pipa jenis PVC dengan diameter 3,5 inchi, 3 inchi, 2,5 inchi dan 2 inchi serta memiliki panjang $4545 \mathrm{~m}$. Setelah semua data di input pada program WaterCAD V8i, selanjutnya dilakukan simulasi sistem jaringan pipa serta menganalisisnya. Hasil simulasi pada pompa dan tandon disajikan pada Gambar 4 berikut.

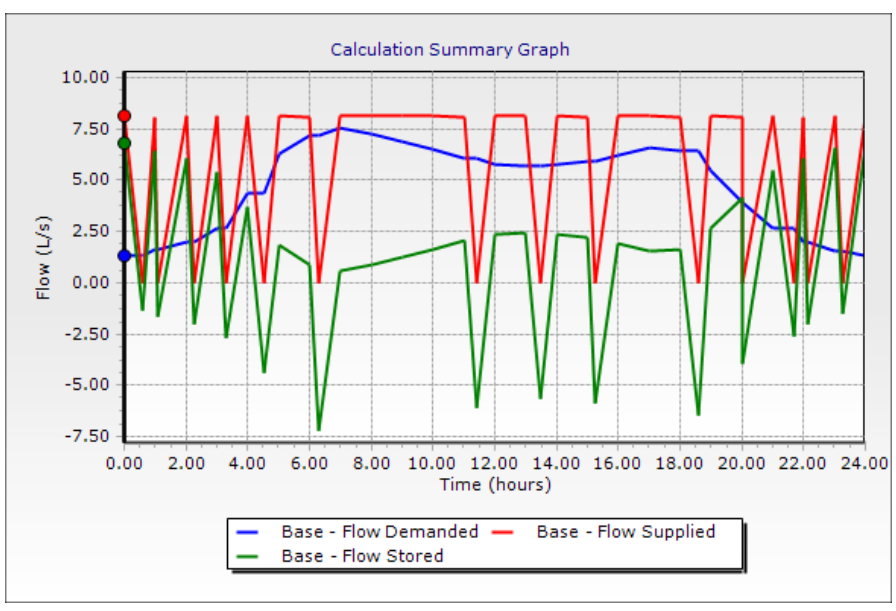

Gambar 4: Grafik Hasil Simulasi pada Pompa dan Tandon

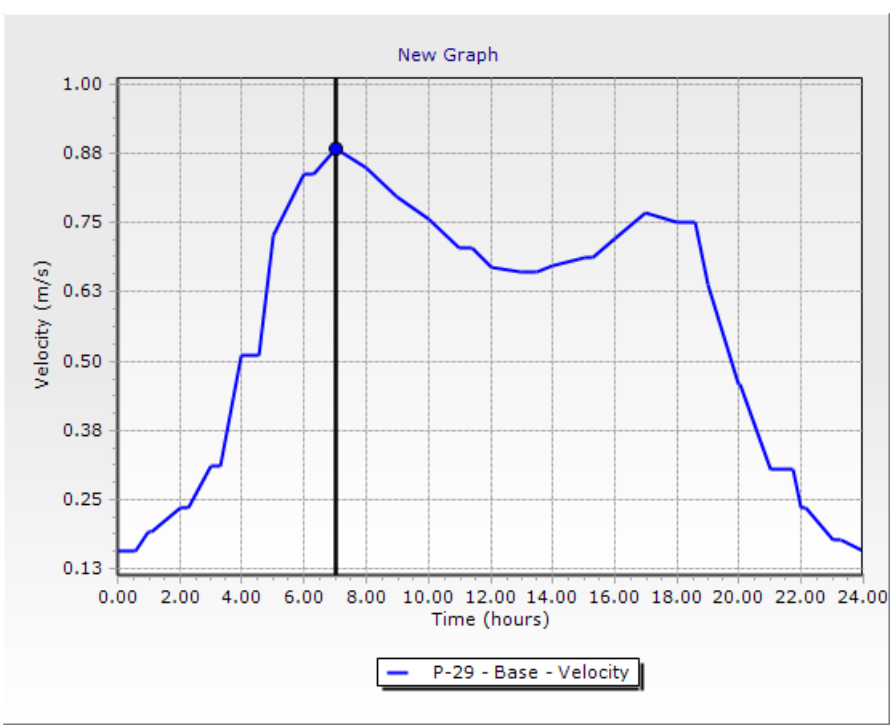

Gambar 5: Grafik Fluktuasi Kecepatan pada Pipa P.29 


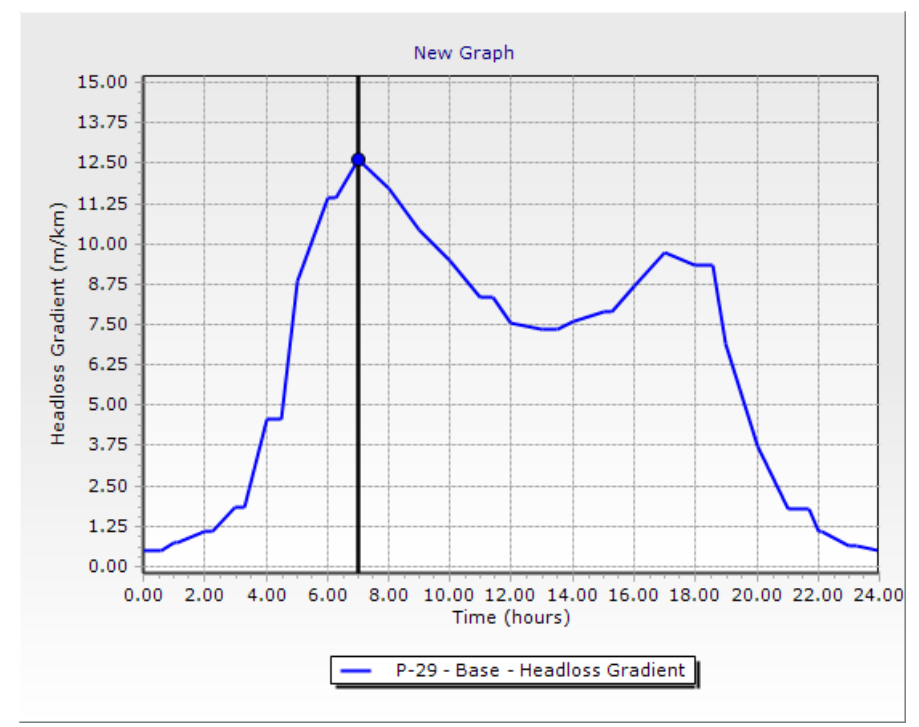

Gambar 6: Grafik Fluktuasi Headloss Gradient pada Pipa P.29

Gambar 5 dan Gambar 6 merupakan hasil simulasi yang dilakukan dengan program WaterCAD V8i pada Pipa 29, kondisi jaringan pipa saat kebutuhan maksimum yaitu pada pukul 07.00 dapat diketahui:

* Kecepatan pada pipa yaitu 0,16-0,88 m/detik. Kecepatan tertinggi terjadi pada saat pukul 07.00 sebesar $0,88 \mathrm{~m} /$ detik dan kecepatan terendah terjadi pada pukul 00.00 sebesar $0,16 \mathrm{~m} /$ detik.

* Berdasarkan hasil simulasi yang telah dijalankan pada sistem jaringan pipa P.29 dapat diperoleh nilai headloss gradient 12,61 m/km pada pukul 07.00 .

* Berdasarkan hasil simulasi yang telah dijalankan pada jaringan pipa distribusi dari tandon sampai ke daerah layanan yaitu dari P.19 - P.71 didapatkan angka headloss gradient yang telah sesuai dengan SNI yang diijinkan yaitu antara $0-15 \mathrm{~m} / \mathrm{km}$.

Setelah dilakukan analisa dan perhitungan dengan program WaterCAD V8i didapatkan bahwa sistem jaringan distribusi pada daerah studi layak dan dapat berfungsi dengan baik dan memenuhi seluruh kriteria perencanaan yang sesuai dengan pedoman SNI serta mampu memenuhi seluruh kebutuhan pelanggan.

\section{Kesimpulan}

Total jumlah penduduk di Desa Rejosari berdasarkan proyeksi penduduk metode aritmatik sampai tahun 2039 adalah sebesar 4449 jiwa. Total kebutuhan air bersih untuk memenuhi seluruh masyarakat yang ada di 3 dusun di Desa Rejosari sampai dengan tahun 2039 dengan kondisi 100\% penduduk terlayani adalah sebesar 4,90 1/dt.

Dari hasil analisa dan evaluasi pada sistem jaringan perpipaan untuk keadaan existing (2019) menggunakan WaterCADV8i diperoleh adanya beberapa pipa pada sistem jaringan distribusi pada daerah studi yang belum memenuhi syarat kecepatan minimal $0,1 \mathrm{~m} / \mathrm{s}$ pada pukul 00.00. Namun pada pukul 07.00 syarat kecepatan minimal dapat terpenuhi. Pada pukul 00.00 kecepatannya lebih rendah dari kecepatan minimal yang diperbolehkan sebesar 
$0,1 \mathrm{~m} /$ detik. Kondisi ini diakibatkan oleh debit air yang dibutuhkan relatif sedikit di pukul 00.00-01.00. Walaupun kecepatannya ada dibawah batas minimal yang diperbolehkan, akan tetapi kondisi seperti ini bisa diterima dikarenakan terjadi di waktu penggunaan air yang sedikit. Namun dari keseluruhan sistem jaringan distribusi masih layak untuk digunakan. Setelah dilakukan evaluasi terhadap kebutuhan air bersih untuk keadaan existing (2019) dari pengambilan debit 5 liter/detik diketahui mampu melayani $100 \%$ dari jumlah SR di daerah pelayanan HIPPAM Sumber Hidup yaitu dapat melayani 320 SR.

Pada tahapan pengembangan sistem jaringan perpipaan di Desa Rejosari direncanakan untuk menambah area pelayanan menuju Dusun Tunjungsari dan juga penambahan prosentase pelayanan untuk Dusun yang sudah terlayani. Pergantian diameter pada pipa transmisi dengan diameter yang lebih besar dari awalnya 3 inchi di ganti dengan diameter 4 inchi perlu dilakukan untuk bisa memenuhi seluruh kriteria perencanaan yang sesuai dengan pedoman SNI. Dari hasil analisa dan perhitungan menggunakan WaterCADV8i kondisi jaringan instalasi perpipaan di wilayah penelitian layak, dapat beroperasi secara normal, dan dapat memenuhi seluruh kebutuhan masyarakat. Hal ini didasarkan pada kriteria yang telah terpenuhi yaitu headloss yang memenuhi syarat $0-15 \mathrm{~m} / \mathrm{km}$, tekanan yang menghasilkan nilai minimum pada standart yang telah ditentukan 0,5-8 atm dan kecepatan yang juga memenuhi syarat $0,1-2,5 \mathrm{~m} / \mathrm{s}$, sehingga dapat diartikan bahwa airnya bisa mengalir 24jam per hari dan juga tekanannya terpenuhi.

Dalam sebuah perencanaan jaringan perpipaan diperlukan data-data pendukung yang memiliki akurasi tinggi dan lengkap guna mendapatkan hasil yang lebih baik, oleh karena itu HIPPAM Sumber Hidup diharapkan mendata secara detail tentang titik-titik pengambilan, sambungan perpipaan, dan perubahan penggunaan air oleh pelanggan pada tiap-tiap jamnya. Pengumpulan data ini sangat bermanfaat karena dapat digunakan untuk merencanakan sistem jaringan perpipaan yang lebih baik lagi di masa depan. Ketika merencanakan jaringan instalasi perpipaan untuk hasil yang terbaik, dapat dipertimbangkan sebuah program yaitu WaterCAD.

\section{Daftar Pustaka}

[1] Muliakusumah, Sutarsih, Proyeksi Penduduk. Jakarta: Fakultas Ekonomi UI, 2000 .

[2] Bentley Methods, User's Guide WaterCAD V8i for Windows WATERBUY CT. USA: Bentley Press, 2007.

[3] Departemen Pekerjaan Umum, Peraturan Menteri Pekerjaan Umum No: 18/PRT/M/2007 Tentang Penyelenggaraan Pengembangan SPAM. Jakarta: Ditjen PU, 2007.

[4] Linsley, Ray K, dan Yoseph B. Franzini, Teknik Sumber Daya Air. Jakarta: Erlangga, 1996.

[5] Priyantoro, Dwi, Hidraulika Saluran Tertutup. Malang: Jurusan Pengairan Fakultas Teknik Universitas Brawijaya, 1991.

[6] Triatmodjo, Bambang, Hidrolika I. Yogyakarta: Beta Offset, 1996. 
[7] Triatmodjo, Bambang, Hidrolika II. Yogyakarta: Beta Offset, 2003.

[8] Departemen Pekerjaan Umum, Pedoman Kebijakan Program Pembangunan Prasarana Kota Terpadu (P3KT). Jakarta: Ditjen Cipta karya, 1994.

[9] Dake, JMK, Hidrolika Teknik. Jakarta: Erlangga, 1985.

[10] Webber, N. B, Fluid Mechanics For Civil Engineering. London: Chapman and Hall, 1971. 